\title{
Stanowisko polskich ekspertów dotyczące zastosowania leku brentuksymab vedotin w leczeniu chorych na pierwotne chłoniaki skóry CD30+
}

\section{Polish experts' opinion concerning brentuximab vedotin in the treatment of patients with primary cutaneous lymphomas with CD30 expression}

\author{
Małgorzata Sokołowska-Wojdyło1, ${ }^{1}$, Jan Walewski², ${ }^{2}$, Wiesław W. Jędrzejczak ${ }^{4}$, \\ Tadeusz Robak ${ }^{5}$, Monika Prochorec-Sobieszek ${ }^{2,6,7}$, Jan Maciej Zaucha ${ }^{2,8}$, \\ Alina Jankowska-Konsur ${ }^{2,} 9$, Monika Słowińska ${ }^{10}$, Ewa Chmielowska ${ }^{2,11}$, \\ Lidia Rudnicka ${ }^{12}$, Sebastian Giebel ${ }^{2,13}$ \\ ${ }^{1}$ Katedra i Klinika Dermatologii, Wenerologii i Alergologii, Gdański Uniwersytet Medyczny \\ ${ }^{2}$ Polska Grupa Badawcza Chłoniaków \\ ${ }^{3}$ Centrum Onkologii - Instytut im. Marii Skłodowskiej-Curie, Warszawa \\ ${ }^{4}$ Katedra i Klinika Hematologii, Onkologii i Chorób Wewnętrznych SPCSK, Warszawa \\ ${ }^{5}$ Katedra i Klinika Hematologii, Uniwersytet Medyczny w Łodzi \\ ${ }^{6}$ Zakład Diagnostyki Hematologicznej, Instytut Hematologii i Transfuzjologii, Warszawa \\ ${ }^{7}$ Zakład Patologii i Diagnostyki Laboratoryjnej, Centrum Onkologii — Instytut im. Marii Skłodowskiej-Curie, Warszawa \\ ${ }^{8}$ Katedra i Klinika Hematologii i Transplantologii, Gdański Uniwersytet Medyczny \\ ${ }^{9}$ Katedra i Klinika Dermatologii, Wenerologii i Alergologii, Uniwersytet Medyczny we Wrocławiu \\ ${ }^{10}$ Klinika Dermatologiczna, Wojskowy Instytut Medyczny \\ ${ }^{11}$ Centrum Onkologii, Bydgoszcz \\ ${ }^{12}$ Katedra i Klinika Dermatologiczna, Warszawski Uniwersytet Medyczny \\ ${ }^{13}$ Klinika Transplantacji Szpiku i Hematoonkologii, Instytut Onkologii, Gliwice
}

\begin{abstract}
Streszczenie
Do pierwotnych chtoniaków skóry T-komórkowych (CTCL) z ekspresja CD30+ należa pierwotny skórny chtoniak anaplastyczny z duzych komórek (pcALCL), lymphomatoid papulosis (LyP), a także ziarniniak grzybiasty (MF) i zespót Sézary'ego (SS), spośród których u części można stwierdzić ekspresje CD30+. Istniejace metody terapii nie pozwalaja na wyleczenie pacjenta chorujacego na wymienione wyżej odmiany chtoniaków. Ponadto skuteczność dostęnych metod jest szczególnie ograniczona w zaawansowanych stadiach choroby. Na podstawie wyników najnowszych badan eksperci rekomenduja, aby brentuksymab vedotin (BV) byt dostępny w Polsce do leczenia dorostych pacjentów z CTCL z ekspresja CD30, u których uprzednio stosowano co najmniej jedno leczenie systemowe. W stadium MF IIB i wyższym leczenie BV powinno być preferowane $w$ stosunku do terapii beksarotenem lub metotreksatem (MTX) ze wzgledu na wyższa skuteczność nowego leku. We wczesnych stadiach MF (IB-IIA) należy rozważyć leczenie BV alternatywnie do stosowania beksarotenu (po nieskuteczności leczenia miejscowego, fototerapii i terapii interferonem i/lub MTX).
\end{abstract}

Adres do korespondencji: Małgorzata Sokołowska-Wojdyło, Katedra i Klinika Dermatologii, Wenerologii i Alergologii, Gdański Uniwersytet Medyczny, ul. Kliniczna 1a, 80-402 Gdańsk, tel. +48 5834925 80, faks +48 583492586 , e-mail: mwojd@gumed.edu.pl 
Skuteczność leczenia BV wykazano u chorych z pcALCL zarówno we wczesnej fazie z obecnościa zmian ograniczonych do skóry, jak i w postaci zaawansowanej z pozaskórna lokalizacja zmian.

Słowa kluczowe: brentuksymab vedotin, ziarniniak grzybiasty, pierwotnie skórny chłoniak anaplastyczny z komórek T, lymphomatoid papulosis, chłoniak CD30+

Hematologia 2018; 9, 2: 83-89

\begin{abstract}
The group of primary cutaneous T-cell lymphomas (CTCL) expressing CD30+ consists of primary cutaneous anaplastic large-cell lymphoma (pcALCL), lymphomatoid papulosis (LyP), some cases of mycosis fungoides (MF) and Sézary syndrome (SS). It is well known that affected patient cannot be cured completely by available therapeutic methods. In addition, the effectiveness of available therapies is especially limited in advanced stages of the disease. Based on the results of the most recent trials, the experts recommend that brentuximab vedotin $(B V)$ should be reimbursed in Poland for the treatment of adult patients with CTCL expressing CD30 who have had at least one prior systemic treatment. In case of $M F B V$ should be preferred to bexarotene or methotrexate (MTX) therapy due to the higher efficacy in stage IIB or higher. BV treatment should be also considered as an alternative to bexarotene (after ineffectiveness of local treatment, phototherapy and interferone/MTX therapy) in early stages of $M F$ (IB-IIA).
\end{abstract}

Key words: brentuximab vedotin, mycosis fungoides, primary cutaneous anaplastic T-cell lymphoma, lymphomatoid papulosis, CD30+ lymphoma

Hematologia 2018; 9, 2: 83-89

\section{Wprowadzenie}

Pierwotne chłoniaki skóry to grupa heterogennych nowotworów układu chłonnego o różnorodnym obrazie klinicznym. Zgodnie $z$ klasyfikacją Światowej Organizacji Zdrowia (WHO, World Health Organization) do najczęstszych rozrostów w tej grupie należą ziarniniak grzybiasty (MF, mycosis fungoides) oraz rozrosty limfoproliferacyjne CD30+, tj. pierwotny anaplastyczny chłoniak T-komórkowy skóry (pcATCL, primary cutaneous anaplastic T-cell lymphoma) ilymphomatoid papulosis (LyP). Należy pamiętać, że ekspresję CD30 obserwuje się także w MF i zespole Sézary'ego (SS, Sézary syndrome) [1-5].

\section{Diagnostyka pierwotnych chłoniaków skóry z ekspresją CD30}

Diagnostyka chłoniaków skóry powinna integrować dane kliniczne oraz wyniki badań histopatologicznych, immunofenotypowych oraz, opcjonalnie, molekularnych zgodnie $\mathrm{z}$ zaleceniami ISCL (International Socielty of Cutaneous Lymphoma), NCCN (National Comprehensive Cancer Network) i klasyfikacją WHO z 2017 roku [2-5]. Podstawą rozpoznania pierwotnego chłoniaka skóry T-komórkowego (CTCL, cutaneous T-cell lymphoma) $z$ ekspresją CD30 jest badanie histopatologiczne wycinków ze zmian skórnych uzupełnione o badanie immunohistochemiczne (IHC, immunohistochemistry) obejmujące, zależnie od obrazu mikroskopowego chłoniaka i diagnostyki różnicowej, wybrane przeciwciała $\mathrm{z}$ następującego panelu: $\mathrm{CD} 2$, CD3, CD5, CD7, CD4, CD8, CD30, CD56, CD25, granzym B, EBV-EBER. W MF i SS szczególnie rekomenduje się ocenę antygenu CD30 w przypadku histologicznej transformacji w chłoniaka $z$ dużych komórek (LCT, large cell transformation). W pcALCL ocena CD30 ma znaczenie zarówno diagnostyczne ( $\geq 75 \%$ komórek anaplastycznych $\mathrm{CD} 30+)$, jak i predykcyjne. Oznaczenie antygenu CD30 można wykonać w momencie ustalania rozpoznania chłoniaka lub później - w chwili kwalifikacji do terapii. Typowy immunofenotyp $\mathrm{MF} / \mathrm{SS}$ obejmuje ekspresję następujących antygenów: $\mathrm{CD} 2+, \mathrm{CD} 3+, \mathrm{CD} 5+, \mathrm{CD} 7-, \mathrm{CD} 4+, \mathrm{CD} 8$ (-, rzadko+) CD30-/+, CD26, brak ziarnistości cytotoksycznych, CCR4+, CD45RO +.Z kolei typowy fenotyp pcALCL obejmuje CD30 ( $\geq 75 \%)$, CD4+, zmienną utratę ekspresji CD2/CD5/CD3/CD8 oraz dodatnie ziarnistości cytotoksyczne $(<5 \%)$ [6].

Materiał do biopsji ze zmiany skórnej należy pobrać, jeśli to możliwe, ze skóry kończyn, pośladków, dolnej części pleców, głowy (nie $z$ okolicy łojotokowej i nie ze skóry brzucha, gdyż wyniki badania histopatologicznego biopsji $z$ tych lokalizacji są częściej niejednoznaczne) [3]. Badanie 
histopatologiczne zmian skórnych powinien ocenić ekspert hematopatolog lub dermatopatolog, ponieważ różnicowanie między CTCL CD30+ a innymi chorobami limfoproliferacyjnymi skóry (w tym odczynowymi, np. ciężką postacią atopowego zapalenia skóry) nie jest łatwe i wymaga dużego doświadczenia.

Badanie molekularne rearanżacji genów dla receptora T-komórkowego (TCR, T-cell receptor) metodą polimerazy reakcji łańcuchowej (PCR, polymerase chain reaction) jest pomocne w trudnych diagnostyczne przypadkach różnicowania dermatoz zapalnych i chłoniaka, szczególnie gdy zgodne rearanżacje monoklonalne występują w więcej niż jednej lokalizacji skórnej. Należy zachować ostrożność przy interpretacji wyników badania klonalności, ponieważ monoklonalne rearanżacje TCR mogą występować w zmianach nienowotworowych oraz nie są obecne we wszystkich przypadkach MF/SS [7].

W przypadku braku możliwości ustalenia rozpoznania na podstawie badania histopatologicznego biopsji zmian skórnych alternatywą jest także badanie histopatologiczne podejrzanego o naciek chłoniaka węzła chłonnego. Zaleca się ponowne badanie histopatologiczne zmian skórnych u chorych na MF/SS z podejrzeniem LCT. Dla zachowania jakości badań IHC i molekularnych ważne są prawidłowe techniczne procedury obróbki materiału tkankowego. Także w przypadkach, w których badanie skóry nie pozwala na dokonanie rozpoznania (szczególnie w stopniu T4), zaleca się badanie krwi obwodowej na obecność komórek Sézary'ego w rozmazie krwi obwodowej, badanie metodą cytometrii przepływowej z użyciem panelu CD3, CD4, CD7, CD8, CD26 w celu oceny dominującej populacji komórek $\mathrm{CD} 4+$ ze zwiększonym stosunkiem CD4/CD8 lub nieprawidłowym fenotypem obejmującym utratę antygenu CD7 lub CD26 oraz badanie rearanżacji TCR metodą PCR [6].

Białko CD30 jest przezbłonowym receptorem cytokin należącym do nadrodziny receptorów czynnika martwicy nowotworów (TNF, tumor necrosis factor). Ekspresję CD30 obserwuje się zarówno w komórkach nienowotworowych (aktywowane limfocyty B i T, migdałki/węzły chłonne, rozproszone duże komórki limfoidalne, subpopulacja komórek plazmatycznych), jak i w komórkach nowotworów (chłoniak Hodgkina, chłoniaki nie-Hodgkina, w tym CTCL, raki zarodkowe, nasieniaki, międzybłoniaki) $[8,9]$.

Antygen CD30 oznacza się w jakościowym teście immunohistochemicznym, wykorzystując mysie monoklonalne przeciwciało anty-CD30, klon Ber-H2. Dostępne komercyjnie przeciwciała firm
Dako (aktualnie Agilent) i Roche Ventana powinny być zwalidowane zgodnie $z$ zaleceniami producenta. Istnieje możliwość międzynarodowej kontroli zewnętrznej barwienia IHC CD30 w NordiQC. Rozliczanie badań w warunkach polskich odbywa się poprzez pakiet finansowy klinik (patomorfologii nie objęto procedurami kosztowymi w Narodowym Funduszu Zdrowia). Koszt badania wynosi około 80 PLN. Ekspresja antygenu CD30 w MF lub SS jest najczęściej związana $z$ LCT i występuje w 30-50\% przypadków. Podstawa rozpoznania LCT w MF/SS to obecność co najmniej 25\% dużych komórek wśród komórek chłoniaka/limfoidalnych. Częstość występowania LCT zależy od stopnia zaawansowania i występuje w 1,4\%, 27\% i 56-67\% — odpowiednio - w fazie wczesnej IA-IIA, IIB oraz w IV. Ekspresję CD30 obserwuje się również w MF bez cech transformacji. Należy pamiętać, że ekspresja CD30 może być różna w kilku biopsjach pobranych $\mathrm{w}$ tym samym czasie od tego samego pacjenta $z$ MF $[8,9]$.

Diagnostyką chłoniaków skóry w Polsce zajmują się ośrodki akademickie i instytuty zlokalizowane $\mathrm{w}$ dużych miastach. Cykliczne spotkania sekcji hematopatologów Polskiej Grupy Badawczej Chłoniaków (PLRG, Polish Lymphoma Research Group) pozwoliły na oszacowanie liczby ośrodków i specjalistów w tej dziedzinie. Jest 19 ośrodków (2 pełnoprofilowe $z$ patomorfologiczną histopatologiczną diagnostyką ekspercką w Warszawie i Krakowie), około 25 hematopatologów i 3 dermatopatologów. Badania molekularne rearanżacji TCR wykonuje Zakład Diagnostyki Hematologicznej Instytutu Hematologii i Transfuzjologii w Warszawie.

\section{Brentuksymab vedotin}

Brentuksymab vedotin (BV) jest koniugatem przeciwciała anty-CD30 i jednometylowanej aurystatyny E (MMAE, monomethyl auristatin E) działającej na wrzeciono kariokinetyczne. Połączenie BV z CD30 na powierzchni komórki zapoczątkowuje internalizację kompleksu BV-CD30. Jednometylowana aurystatyna $\mathrm{E}$ jest uwalniana wewnątrz komórki po rozkładzie proteolitycznym. Wiązanie MMAE z tubuliną rozrywa sieć mikrotubuli w komórce, co indukuje zatrzymanie cyklu komórkowego i prowadzi do apoptozy komórek CD30+, $\mathrm{w}$ tym nowotworowych. Brentuksymab vedotin jest zarejestrowany $\mathrm{w}$ Polsce, zgodnie $z$ charakterystyką produktu leczniczego (ChPL), do leczenia dorosłych pacjentów $z$ nawrotowym lub opornym na leczenie chłoniakiem Hodgkina (HL, Hodgkin lymphoma) CD30+ po przeszczepieniu 
autologicznych krwiotwórczych komórek macierzystych (auto-HSCT, autologous hematopoietic stem cell transplantation) lub po co najmniej dwóch wcześniejszych terapiach, w przypadku gdy chory nie kwalifikuje się do allo-HSCT lub chemioterapii wielolekowej. Ponadto BV jest zarejestrowany w Polsce do terapii chorych na HL CD30+ obciążonych wysokim ryzykiem nawrotu lub progresji choroby po auto-HSCT, a także pacjentów $z$ nawrotowym lub opornym na leczenie układowym chłoniakiem anaplastycznym $z$ dużych komórek (sALCL, systemic anaplastic large cell lymphoma). W krajach Unii Europejskiej BV zarejestrowano 15 grudnia 2017 roku do leczenia chłoniaków pierwotnie skórnych T-komórkowych (CTCL, primary cutaneous T-cell lymphomas) z ekspresją CD30 + u osób poddanych wcześniej przynajmniej jednej terapii systemowej. Zgodnie $z$ ChPL tego leku zalecana dawka leku wynosi $1,8 \mathrm{mg} / \mathrm{kg} \mathrm{mc}$. w 30-minutowym wlewie dożylnym podawanym co 3 tygodnie. Leczenie należy kontynuować do 16 cykli lub nieakceptowalnej toksyczności leku. Wcześniejsze zakończenie leczenia może być też spowodowane progresją choroby. U pacjentów z zaburzeniami czynności wątroby lub $z$ ciężkimi zaburzeniami czynności nerek zaleca się mniejszą dawkę leku wynoszącą 1,2 mg/kg mc.

W badaniu klinicznym II fazy BV podawano w 16 cyklach 29 chorym na MF i 3 chorym z SS. Odsetek odpowiedzi wyniósł 70\%, a u 79\% odpowiedź utrzymywała się po roku [10]. U chorych z SS uzyskano różne odpowiedzi na leczenie - jedną całkowitą remisję (CR, complete remission), jedną częściową remisję (PR, partial remission) oraz jedną proregresję choroby (PD, progression of the disease). Najczęstszym powikłaniem była polineuropatia obwodowa, której nasilenie w stopniu G3-G4 wystąpiło u 3\% chorych [10]. W innym badaniu klinicznym II fazy [11] odpowiedź na leczenie BV uzyskano u 73\% chorych na CTCL, w tym u wszystkich 9 chorych na LyP, u 2 na pcALCL, u $54 \%$ chorych na MF (15/28) i 50\% chorych $z$ MF/SS (5/10). Co interesujące, nie zaobserwowano neuropatii obwodowej w stopniu G3 lub wyższym. Innymi częstymi działaniami niepożądanymi były: zmęczenie, nudności, łysienie, neutropenia, anoreksja, osutki skórne, dyspepsja, biegunka, infekcje skórne, zmniejszenie masy ciała [11].

Skuteczność i bezpieczeństwo BV w monoterapii oceniono w otwartym, randomizowanym, wieloośrodkowym badaniu III fazy u 128 chorych $\mathrm{z}$ rozpoznaniem MF lub pcALCL. Badanie przeprowadzono w 52 ośrodkach w 13 krajach, w tym w 2 ośrodkach polskich (Warszawa, Bydgoszcz) [12].
Przed włączeniem do badania klinicznego pacjenci $z$ pcALCL byli leczeni metodą radioterapii lub poddani co najmniej jednemu leczeniu systemowemu. Pacjentów z MF leczono wcześniej co najmniej jedną metodą systemową. W grupie aktywnego leczenia chorzy otrzymali BV w dawce $1,8 \mathrm{mg} / \mathrm{kg}$ mc. co 3 tygodnie (do 16 cykli). Mediana liczby cykli leczenia u pacjentów leczonych BV wyniosła 12-13 (269 dni). W grupie kontrolnej chorzy otrzymywali, zgodnie $z$ decyzją lekarza, beksaroten $\left(300 \mathrm{mg} / \mathrm{m}^{2} \mathrm{raz} / \mathrm{d}\right.$.) lub metotreksat (MTX; 5-50 mg doustnie raz/tydz.) przez okres do 48 tygodni. Mediana okresu obserwacji wyniosła 22,9 miesiąca. Jako pierwszorzędowy punkt końcowy w badaniu wyznaczono odsetek chorych $z$ odpowiedzią na leczenie utrzymującą się przez co najmniej 4 miesiące (ORR4, 4-month overall response rate). Za wyborem takiego punktu przemawiała specyfika choroby z możliwością wystąpienia krótkotrwałych, nieistotnych klinicznie odpowiedzi na leczenie (możliwych także po podaniu leków zmniejszających odczyn zapalny), przy jednoczesnym częstym oczekiwaniu na rzeczywistą remisję wynoszącym około 3 miesiące. Ponadto za wyborem tego punktu końcowego przemawiała możliwość najbardziej miarodajnej oceny efektu netto pojedynczego leku (bez wpływu kolejnych linii leczenia) w sytuacji, gdy u części chorych nie jest możliwa ocena czasu wolnego od progresji (PFS, progression-free survival) ze względu na zmianę leczenia $z$ powodu nasilenia objawów podmiotowych (ból, świąd) przed diagnozą progresji metodami obiektywnymi [12].

Odsetek chorych $z$ obiektywną odpowiedzią na BV utrzymującą się przez co najmniej 4 miesiące (ORR4) wyniósł 56\%, natomiast w grupie kontrolnej (pacjenci leczeni beksarotenem lub MTX) odpowiedź stwierdzono tylko u 12,5\% ( $<<0,0001)$. Różnicę tę zaobserwowano zarówno u pacjentów $z$ MF (50\% v. 10\%), jak chorych na pcALCL (75\% v. 20\%). Znamiennie wyższy odsetek ORR4 u chorych leczonych BV wykazano w porównaniach $z$ chorymi leczonymi zarówno beksarotenem $(56 \%$ v. $16 \%$ ), jak i MTX (56\% v. 8\%). U chorych na MF odpowiedź na terapię beksarotenem lub MTX obserwowano prawie wyłącznie $\mathrm{u}$ chorych $\mathrm{w}$ stadium IA-IIA ( $\mathrm{z}$ wyjątkiem 1 chorego w stadium IIB [1/19]). Żaden chory w stadium IIIA lub wyższym nie uzyskał odpowiedzi na leczenie beksarotenem lub MTX [13]. Natomiast ORR4 u chorych leczonych BV stwierdzano we wszystkich stadiach zaawansowania MF. W stadiach IA-IIA odpowiedź ORR4 wyniosła 40\% (6/15), w IIB - 63\% (12/19), w IIIA-IIIB - 50\% (2/4), w IVA $-100 \%(2 / 2)$, a w IVB $-29 \%(2 / 7)$ [13]. 
W przypadku pcALCL odpowiedzi ORR4 na beksaroten lub MTX obserwowano jedynie we wczesnych stadiach bez obecności zmian pozaskórnych w 27\% (3/11) przypadków. Leczenie BV skutkowało ORR4 zarówno u chorych ze zmianami ograniczonymi do skóry $(89 \%$; 8/9), jak i u chorych w stadium zaawansowanym choroby ze zmianami pozaskórnymi $(57 \%$; 4/7) $[12,13]$.

Warto podkreślić, że zaobserwowano znaczną zmienność w ekspresji CD30 zarówno u różnych pacjentów, jak i u tego samego chorego (w kilku biopsjach $z$ różnych zmian skórnych). Co ciekawe, odpowiedzi ORR4 na BV obserwowano zarówno u chorych $\mathrm{z}$ niską, jak i wysoką ekspresją CD30. U chorych leczonych BV nie tylko ORR4, ale i PFS były korzystniejsze niż w grupie kontrolnej, niezależnie od poziomu ekspresji CD30 [12, 13].

Mediana PFS w grupie leczonej BV wyniosła 16,7 miesiąca w porównaniu z 3,5 miesiąca $\mathrm{w}$ grupie kontrolnej (współczynnik ryzyka [HR, hazard ratio $=0,27 ; \mathrm{p}<0,0001)$ wedlug kryteriów Europejskiej Agencji Leków (EMA, European Medicines Agency) oraz 17,2 w porównaniu z 3,5 miesiąca (HR $=0,181 ; \mathrm{p}<0,0001)$, odpowiednio, według kryteriów Agencji ds. Żywności i Leków (FDA, Food and Drug Administration). Mediana PFS w grupie leczonej BV (16,7 mies.) była znamiennie wyższa zarówno $\mathrm{w}$ porównaniu $\mathrm{z}$ terapią MTX (2,3 mies.), jak i beksarotenem (4,5 mies.). $\mathrm{W}$ grupie chorych $z \mathrm{MF}$ leczonych BV poprawa $\mathrm{PFS}$ wyniosła ponad rok $(15,9 v$. 3,5 mies.; $\mathrm{p}<0,05)$, a $\mathrm{w}$ grupie chorych na pcALCL - prawie 2 lata (27,5 v. 5,3 mies.; $\mathrm{p}<0,05)$ (wg kryteriów EMA). Nie przeprowadzono analizy przeżycia całkowitego (OS, overall survival) (29/128 zgonów) ze względu na nadal trwającą obserwację $[12,13]$.

Leczenie BV wiązało się ze znamiennie wyższą jakością życia chorych. Ograniczenie nasilenia objawów choroby zgłaszanych przez pacjentów i mierzonych w skali Skindex-29 było znamiennie statystycznie większe w grupie leczonych BV $(-27,96)$ niż w grupie kontrolnej $(-8,62)$ $(\mathrm{p}<0,0001)$ [12].

Działania niepożądane w stopniu G3-G4 opisano u $41 \%$ (27/66) chorych leczonych BV i $47 \%$ (29/62) pacjentów z grupy kontrolnej. Neuropatia obwodowa podczas leczenia BV wystąpiła u $67 \%$ $(44 / 66)$ chorych, w tym u $9 \%(6 / 66)$ w stopniu G3. W grupie leczonej beksarotenem najczęściej występowała hipertriglicerydemia (30\% chorych), w tym u 5 (14\%) chorych w stopniu G3, a u $3(8 \%)$ chorych w stopniu G4 [12].

\section{Leczenie pierwotnych chłoniaków skórnych w Polsce}

W praktyce ścieżkę postępowania terapeutycznego w przebiegu pierwotnych chłoniaków skórnych w Polsce determinują częściowo specjalizacja lekarza prowadzącego leczenie, a także specyfika danego ośrodka. Mimo heterogenności w postępowaniu między ośrodkami terapie w nich stosowane $\mathrm{w}$ warunkach codziennej praktyki klinicznej zawierają się w koszyku terapii nakreślonym w wytycznych Polskiego Towarzystwa Onkologii oraz rekomendacjach Sekcji Chłoniaków Skóry PLRG [3-5]. W przypadku MF — po braku skuteczności miejscowych glikokortykosteroidów i retinoidów - metodą $z$ wyboru jest fototerapia UVB311 w przypadku rumieni oraz PUVA (psoralen + ultrafiolet A) w przypadku nacieków, będąca $z$ biologicznego punktu widzenia metodą leczenia systemowego. Gdy ta nie przynosi efektu, to wdraża się stosowanie interferonu alfa (IFN $\alpha$ ), MTX i beksarotenu. Ze względu na większą dostępność (lek możliwy do zaordynowania zarówno przez hematologa, jak i dermatologa) po zastosowaniu fototerapii w przebiegu MF, jako leczenie kolejnego rzutu zdecydowanie częściej niż IFN $\alpha$, wprowadzany jest MTX. Metotreksat w terapii MF standardowo podaje się w małych dawkach, tj. 10-30 mg tygodniowo. $\mathrm{W}$ ścieżce terapeutycznej poprzedzającej włączenie terapii beksarotenem w terapii MF, jeżeli u pacjenta zastosowano MTX bez uprzedniego leczenia IFN, terapia IFN niejednokrotnie jest w ogóle pomijana $(\sim 40 \%)$ i chory jest bezpośrednio kwalifikowany do terapii beksarotenem. Terapię beksarotenem $\mathrm{w}$ większości przypadków $(\sim 80 \%)$ prowadzi się zgodnie ze schematem, który zaproponowano w zapisach obecnie funkcjonującego programu lekowego, tj. rozpoczęcie leczenia od dawki $150 \mathrm{mg} / \mathrm{m}^{2}$ dożylnie/dobę podawanej przez 14 dni, $z$ następowym zwiększeniem dawki do $300 \mathrm{mg} / \mathrm{m}^{2}$. Wynika to $z$ obawy o wystapienie hiperlipidemii i hepatotoksyczności. Jako wskaźnik skuteczności decydujący o przerwaniu leczenia beksarotenem w większości przypadków $(\sim 80 \%)$ wybierana jest progresja choroby w trakcie leczenia, a tylko niewielki odsetek stanowią przypadki nieakceptowalnych dolegliwości subiektywnych przy jednoczesnym braku obiektywnej progresji. Pacjentowi, u którego odstąpiono od leczenia beksarotenem, a wcześniej był leczony IFN $\alpha$, pozostają w Polsce leczenie w ramach badań klinicznych, radioterapia pojedynczych guzów oraz 
przeszczepienie allogenicznych krwiotwórczych komórek macierzystych (allo-HSCT, allogeneic stem cell transplantation). Chemioterapia systemowa powinna być ostateczną alternatywą, gdyż częściej prowokuje groźne dla życia powikłania infekcyjne niż prowadzi do długotrwałych remisji [3-5].

Zgodnie ze wskazaniem rejestracyjnym leczenie BV powinno się stosować u dorosłych chorych $z$ potwierdzonym histologicznie CTCL $z$ ekspresją CD30, w tym w przypadku MF po niepowodzeniu leczenia systemowego między innymi MTX lub IFN lub beksarotenem, a w przypadku pcALCL u chorych, u których zastosowano leczenie metodą radioterapii lub przynajmniej jedno leczenie systemowe, między innymi MTX.

W kontekście dostępnych danych we wczesnych stadiach zaawansowania MF (IB-IIA) po leczeniu miejscowym, fototerapii i terapii IFN/MTX należy rozważyć zarówno podanie beksarotenu, jak i BV. W stadium guzowatym MF (IIB) i o wyższym zaawansowaniu leczenie BV powinno być preferowane $\mathrm{w}$ stosunku do alternatywnej terapii beksarotenem lub MTX ze względu na większą skuteczność takiego postępowania wykazaną w badaniu klinicznym ALCANZA [10, 12].

\section{Stanowisko grupy ekspertów}

Dostępne metody terapii ( $\mathrm{z}$ wyjątkiem allo-HSCT w wybranych sytuacjach klinicznych) nie dają możliwości wyleczenia chorego na CTCL. Przeszczepienie allogenicznych krwiotwórczych komórek macierzystych rzadko znajduje zastosowanie ze względu na duże ryzyko poważnych powikłań i zgonu. Zważywszy na patomechanizm choroby i możliwość uzyskania krótkotrwałych odpowiedzi (w tym również z powodu odczynowej proliferacji limfocytów T i efektów leczenia przeciwzapalnego), w ocenie efektów leczenia należy zwrócić uwagę na parametry opisujące długość utrzymywania się efektu terapeutycznego. Podstawą do rejestracji BV u chorych $z$ chłoniakami skóry CD30 + były wyniki badania klinicznego ALCANZA III fazy, w którym wykazano wyższą skuteczność oraz większą poprawę jakości życia przy porównywalnej tolerancji leczenia w porównaniu $z$ terapią beksarotenem lub MTX. Odsetek długotrwałych odpowiedzi na leczenie trwających przynajmniej 4 miesiące u chorych leczonych BV wyniósł $56 \%$ w porównaniu $z 12 \% \mathrm{w}$ grupie kontrolnej. Leczenie BV pozwoliło wydłużyć o 13 miesięcy PFS (16,5 v. 3,5; $\mathrm{HR}=0,27 ; \mathrm{p}<0,0001)$. Poprawę tę uzyskano zarówno u chorych leczonych MTX, jak i beksarotenem, jak również zarówno w grupie $z$ rozpoznaniem
pcALCL jak i MF. Potwierdza to wysoką skuteczność leku w tym wskazaniu w porównaniu $z$ dotychczas dostępnymi metodami terapii $[12,13]$.

Należy zauważyć, że w przypadku rzadko występującej jednostki chorobowej, jaką są chłoniaki pierwotnie skórne, badanie III fazy ALCANZA przeprowadzono w dużej grupie chorych $(\mathrm{n}=128)$. Jego znaczącą wartością jest wykazanie wyższej skuteczności BV w bezpośrednim porównaniu $z$ leczeniem obowiązującym $\mathrm{w}$ polskiej praktyce klinicznej [10, 12].

Wyniki cytowanych badań uzasadniają potrzebę zapewnienia dostępności BV dla chorych na CTCL CD30+ w Polsce, których poddano uprzednio co najmniej jednemu leczeniu systemowemu. W szczególności należy rozważyć leczenie BV u chorych na MF oraz pcALCL, choć wyniki badań nad BV wskazują również na wartość takiej terapii u chorych z SS [12].

Jako kryterium włączenia do leczenia należy przyjąć rozpoznanie pierwotnego chłoniaka skóry z ekspresją antygenu CD30 potwierdzoną histopatologicznie w badaniu immunohistochemicznym na podstawie oceny co najmniej dwóch biopsji zmian w MF i jednej biopsji zmian w pcALCL. U chorych na MF wymagane powinno być wcześniejsze, zakończone niepowodzeniem leczenie, $\mathrm{w}$ tym przede wszystkim z zastosowaniem MTX, IFN, beksarotenu lub chemioterapii systemowej. U chorych na pcALCL należy rozważyć BV po niepowodzeniu wcześniejszego leczenia systemowego.

We wczesnych stadiach zaawansowania MF (IB-IIA) po leczeniu miejscowym, fototerapii i terapii IFN/MTX zasadne jest rozważenie wdrożenia BV alternatywnie do beksarotenu. W stadium MF IIB i wyższym leczenie BV powinno się preferować w stosunku do terapii beksarotenem lub MTX ze względu na wyższą skuteczność BV.

Leczenie chorych na chłoniaki skóry wymaga podejścia wielospecjalistycznego $\mathrm{z}$ udziałem dermatologa, patomorfologa, hematologa lub onkologa. Dostęp do leczenia BV powinien być zapewniony zarówno w ośrodkach hematologicznych i onkologicznych, jak i dermatologicznych — zgodnie z praktyką i specjalizacją lokalnych ośrodków.

\section{Konflikt interesów}

Małgorzata Sokołowska-Wojdyło: członek Advisory Board Takeda; honoraria za wykłady: Astellas, Avene, General Topics, Gilead, Iwostin, La Roche Posay, Leo, Roche, Valeant; stypendia wyjazdowe: Celgene, General Topics, Roche; funkcje konsultacyjne: General Topics. 
Jan Walewski: udział w naukowej grupie doradczej: Takeda, Janssen-Cilag, Roche, Celgene, Amgen, BMS, Incyte; granty badawcze lub edukacyjne dla instytucji: Roche, Janssen-Cilag, Takeda, GSK/Novartis; honoraria za wykłady: Roche, Takeda, Celgene, Servier, Janssen-Cilag; koszty udziału w konferencji: Roche.

Wiesław W. Jędrzejczak: członek Advisory Board Takeda, udział w badaniach sponsorowanych przez Takeda.

Tadeusz Robak: członek Advisory Board Takeda.

Monika Prohorec-Sobieszek: członek Advisory Board Takeda i MSD; honoraria za wykłady: MSD, Novartis, Roche; stypendia wyjazdowe: Celgene, Roche.

Jan Maciej Zaucha: honoraria za wykłady: Celgene, Janssen, Roche, Abbott; członek Advisory Board Takeda; stypendia wyjazdowe: Roche, Janssen.

Alina Jankowska-Konsur: członek Advisory Board Takeda.

Monika Słowińska: honoraria za wykłady: Novartis, BMS, Medac i Sanofi; stypendia wyjazdowe BMS, Roche, członek Advisory Board Takeda.

Lidia Rudnicka: członek międzynarodowej rady naukowej: Stiefel, Janssen-Cilag, organizator konferencji we wspólpracy z: LaRoche Posay, Vichy, Pierre Fabre, Leo; wsparcie udziału w konferencjach międzynarodowych: Abbvie, Medac; funkcje konsultacyjne dla Abbvie, Lilly, Novartis, Celgene.

Ewa Chmielowska i Sebastian Giebel deklarują brak konfliktu interesów.

\section{Piśmiennictwo}

1. Willemze R, Jaffe ES, Burg G, et al. WHO-EORTC classification for cutaneous lymphomas. Blood. 2005; 105(10): 3768-3785, doi: 10.1182/blood-2004-09-3502, indexed in Pubmed: 15692063.

2. Swerdlow SH, Campo E E, Harris N. WHO Classification of Tumours of Haematopoietic and Lymphoid Tissues. Revised $4^{\text {th }}$ edition. IARC, Lyon 2017.

3. Sokołowska-Wojdyło M, et al. Chłoniaki pierwotnie skórne rekomendacje diagnostyczno-terapeutyczne Polskiego Towarzystwa Dermatologicznego. Dermatol Rev/Przegl Dermatol. 2017; 104: 243-268.
4. Sokołowska-Wojdyło M. Pierwotne chłoniaki skóry. In: Robak T, Warzocha K. ed. Hematologia. Via Medica, Gdańsk 2016: 1042-1064.

5. Sokołowska-Wojdyło M. Zasady postępowania w chłoniakach pierwotnie skórnych. In: Jędrzejczak WW, Robak T, Podolak-Dawidziak M. ed. Praktyka hematologiczna: praca zbiorowa. Termedia Wydawnictwa Medyczne, Poznań 2015: 271-284.

6. Pimpinelli N, Olsen EA, Santucci M, et al. International Society for Cutaneous Lymphoma. Defining early mycosis fungoides. J Am Acad Dermatol. 2005; 53(6): 1053-1063, doi: 10.1016/j. jaad.2005.08.057, indexed in Pubmed: 16310068.

7. Thurber SE, Zhang B, Kim YH, et al. T-cell clonality analysis in biopsy specimens from two different skin sites shows high specificity in the diagnosis of patients with suggested mycosis fungoides. J Am Acad Dermatol. 2007; 57(5): 782-790, doi: 10.1016/j. jaad.2007.06.004, indexed in Pubmed: 17646032.

8. Edinger JT, Clark BZ, Pucevich BE, et al. CD30 expression and proliferative fraction in nontransformed mycosis fungoides. Am J Surg Pathol. 2009; 33(12): 1860-1868, doi: 10.1097/ /PAS.0b013e3181bf677d, indexed in Pubmed: 19898220.

9. Benner MF, Jansen PM, Vermeer MH, et al. Prognostic factors in transformed mycosis fungoides: a retrospective analysis of 100 cases. Blood. 2012; 119(7): 1643-1649, doi: 10.1182/ /blood-2011-08-376319, indexed in Pubmed: 22160616.

10. Kim YH, Tavallaee M, Sundram U, et al. Phase II Investigator-Initiated Study of Brentuximab Vedotin in Mycosis Fungoides and Sézary Syndrome With Variable CD30 Expression Level: A Multi-Institution Collaborative Project. J Clin Oncol. 2015; 33(32): 3750-3758, doi: 10.1200/JCO.2014.60.3969, indexed in Pubmed: 26195720.

11. Duvic M, Tetzlaff MT, Gangar P, et al. Results of a phase II trial of brentuximab vedotin for CD30+ cutaneous T-cell lymphoma and lymphomatoid papulosis. J Clin Oncol. 2015; 33(32): 3759-3765, doi: 10.1200/JCO.2014.60.3787, indexed in Pubmed: 26261247.

12. Prince HM, Kim YH, Horwitz SM, et al. ALCANZA study group. Brentuximab vedotin or physician's choice in CD30-positive cutaneous T-cell lymphoma (ALCANZA): an international, open-label, randomised, phase 3, multicentre trial. Lancet. 2017; 390(10094): 555-566, doi: 10.1016/S0140-6736(17)31266-7, indexed in Pubmed: 28600132 .

13. Horwitz S, Whittaker S, Duvic M, et al. Response by stage in CD30-positive $(\mathrm{CD} 30+)$ cutaneous $\mathrm{T}$ cell lymphoma (CTCL) patients receiving brentuximab vedotin (BV) vs physician's choice (PC) in the phase 3 ALCANZA study. Hematol Oncol. 2017; 35: 245-247, doi: 10.1002/hon.2438_109.

14. Kim YH, Prince HM, Whittaker S, et al. Brentuximab vedotin vs physician's choice in CTCL patients from the phase 3 ALCANZA study: analysis of outcomes by CD30 expression. Hematol Oncol. 2017; 35: 77-78, doi: 10.1002/hon.2437_65. 